\title{
Assessment of Suitable Areas for Home Gardens for Irrigation Potential, Water Availability, and Water-Lifting Technologies
}

\author{
Tewodros Assefa ${ }^{1, *}$, Manoj Jha ${ }^{2}$, Manuel Reyes ${ }^{3}$, Raghavan Srinivasan 4 (1) \\ and Abeyou W. Worqlul ${ }^{5}$ (I) \\ 1 Department of Energy and Environmental System, North Carolina A\&T State University, \\ Greensboro, NC 27411, USA \\ 2 Department of Civil Engineering, North Carolina A\&T State University, Greensboro, NC 27411, USA; \\ mkjha@ncat.edu \\ 3 Sustainable Intensification Innovation Lab (SIIL), Kansas State University, Manhattan, KS 66506, USA; \\ mannyreyes@ksu.edu \\ 4 Department of Ecosystem Sciences and Management and Biological and Agricultural Engineering, \\ Texas A\&M University, College Station, TX 77843, USA; r-srinivasan@tamu.edu \\ 5 Texas A\&M AgriLife Research Blackland Research \& Extension Center, Temple, TX 76502, USA; \\ aworqlul@brc.tamus.edu \\ * Correspondence: tassefa@aggies.ncat.edu; Tel.: +1-336-457-4092
}

Received: 21 February 2018; Accepted: 13 April 2018; Published: 17 April 2018

\begin{abstract}
The study was conducted in Lake Tana Basin of Ethiopia to assess potentially irrigable areas for home gardens, water availability, and feasibility of water-lifting technologies. A GIS-based Multi-Criteria Evaluation (MCE) technique was applied to access the potential of surface and groundwater sources for irrigation. The factors affecting irrigation practice were identified and feasibility of water-lifting technologies was evaluated. Pairwise method and expert's opinion were used to assign weights for each factor. The result showed that about 345,000 ha and 135,000 ha of land were found suitable for irrigation from the surface and groundwater sources, respectively. The rivers could address about $1-1.2 \%$ of the irrigable land during dry season without water storage structure whereas groundwater could address about $2.2-2.4 \%$ of the irrigable land, both using conventional irrigation techniques. If the seven major dams within the basin were considered, surface water potential would be increased and satisfy about $21 \%$ of the irrigable land. If rainwater harvesting techniques were used, about $76 \%$ of the basin would be suitable for irrigation. The potential of surface and groundwater was evaluated with respect to water requirements of dominant crops in the region. On the other hand, rope pump and deep well piston hand pump were found with relatively the most $(26 \%)$ and the least $(9 \%)$ applicable low-cost water-lifting technologies in the basin.
\end{abstract}

Keywords: irrigation potential; water availability; water-lifting technology; home garden; Lake Tana basin; MCE technique

\section{Introduction}

Agriculture is the backbone of the economy of Ethiopia. It contributes about $48 \%$ to the national gross domestic product (GDP) regarding export, employment and subsistence [1]. A majority of the population lives in rural areas depending on agriculture for their livelihood. The agricultural practices are mainly traditional and using rainfed systems. Rainfall is highly variable in the region, which resulted in periodic drought [2]. Ethiopia usually experiences drought every two to three years [3]. Irrigation plays a significant role to address the adverse effect of rainfall variability and 
improve agricultural production [4]. It is believed that the country has a large potential of land feasible for irrigation. However, only about 4 to $5 \%$ is under irrigation [5]. Identifying suitable land for irrigated agriculture plays an important role in effectively using the available water resources. Most of the farmers (more than 85\%) in Ethiopia cultivates less than 2 ha of land (smallholder farmers) [6]. Low-cost and efficient water application technologies are important to improve water productivity and alleviate food insecurity for smallholder farmers $[2,7,8]$. The rainfed agricultural system needs to move in the direction of irrigated agriculture to sustain livelihoods and ensure food security for smallholder farmers in the region.

Home gardens are considered a sustainable agricultural system as they help to improve both food and nutrition security for smallholder farmers [9]. Home gardening is producing food close to the household on a small plot of land [9-12]. Potentially irrigable lands can be used for home garden development. The size of home gardens range from 25 to $500 \mathrm{~m}^{2}$ and can be extended over time [9]. Ojiewo et al. [13] indicated that a $36 \mathrm{~m}^{2}$ home garden is sufficient to provide a healthy diet for a family of eight for a year. A variety of crops can be grown in home gardens, which include vegetables, fruits, and oil and grain crops. Teff, barley, corn, rice, wheat, beans and millet, khat, onion, cabbage are among the dominant crops grown in the Lake Tana region [14]. Crop water requirements for the dominant crop ranges from $5.2 \mathrm{~mm} /$ day to $8.1 \mathrm{~mm} /$ day [14]. In general, spate irrigation has been traditionally used in Ethiopia [15]. The integration of home gardens with irrigation would help to increase productivity in the region by enabling year-round cropping (i.e., both rainfed and irrigated system). In addition, the home garden provides nutritious food and cash income for smallholder farmers [9].

Surface water is the main source of the current irrigation system, whereas the use of groundwater is limited to domestic water supply. Groundwater use for irrigation, in Ethiopia, is constrained by technology, development and operational cost and lack of understandings of the resource dynamics $[5,16]$. Assessing available water potential and identifying areas where the potential water support irrigated agriculture is vital to increasing water productivity and economical use of land [17,18]. Irrigation schemes can be categorized as small, medium and large depending on the size of the land under irrigation. Awulachew et al. [5] classified irrigation schemes as small ( $<200 \mathrm{ha})$, medium (200-3000 ha) and large-scale irrigation (>3000 ha). Small-scale irrigation schemes are mainly owned and managed by farmers [19]. Irrigation practices in the nation are mainly traditional [20] and range from medium to large-scale. Small-scale irrigation is not well practiced in the nation [21]. However, small-scale irrigation plays an important role in maximizing food production and contributing towards food security in Ethiopia and other Sub-Saharan countries [22-27]. In addition, small-scale irrigation is identified as an effective strategy for climate change adaptation measure [28]. Suitability assessment of low-cost water-lifting technologies will be very helpful to motivate smallholder farmers to grow crops and vegetables at a household level.

Limited research has been done on the assessment of irrigable land and potential of available water resources to enable irrigated agriculture practice in Ethiopia. Mahari and Alebachew [17] evaluated the suitability of soils for irrigation practice based on soils physical and chemical properties in Dejen district of Ethiopia. Their study depicted that about $70 \%$ of Dejen district is suitable for irrigation. Teka et al. [29] also evaluated the suitability of land for surface and drip irrigation based on a parametric evaluation of soil properties and topography for the Korir watershed. The findings of their study showed that about $23 \%$ and $92 \%$ of the watershed is suitable for surface and drip irrigation, respectively. Similarly, Ref. [18] also assessed the suitability of land for surface and drip irrigation considering soil properties and topography in Kilte Awulaelo district. They found about $28 \%$ and $15 \%$ of the district suitable for drip and surface irrigation, respectively. Sultan [30] prepared land suitability map for irrigation based on soil properties and groundwater quality in Fogera district. The results of his study depicted that about $72 \%$ of Fogera district is feasible for irrigation practice. Abraham et al. [31] evaluated the suitability of land for irrigated agriculture using drainage characteristics and soil properties for Smez dam catchment. They categorized almost the entire Smez dam catchment under a moderately suitable class for irrigation practice. Ayalew [32] evaluated the suitability of land for 
surface and sprinkler irrigation considering soil characteristics and topography for Guang Watershed. His results depicted that about $40 \%$ and $5 \%$ of Guang Watershed is suitable for drip and sprinkler irrigation, respectively.

There is a little quantitative study on the potential of water resource for irrigation practice coupled with the potentially irrigable land. Worqlul et al. [14] examined potentially irrigable land and the potential of surface water for irrigation in the Ethiopian highlands, Lake Tana Basin. They considered multiple factors such as climate, rivers, soils, land covers, topography and market centers. Their study found about $11 \%$ of Lake Tana Basin as suitable for irrigation practice from surface water. Irrigable land assessment for home gardening practice from the perspectives of different water sources and applicability of various low-cost water-lifting technologies remains a research gap. This study contributed to filling this gap by incorporating the following points: (1) assessment of irrigable land for home gardens using surface water, groundwater, and rainwater harvesting sources; (2) assessment of water availability considering both surface and groundwater; (3) examining the applicability of low-cost water-lifting technologies. In addition, more refined inputs were used for this study particularly for river networks, market outlets, and road networks. The results from this study would help local decision makers and stakeholders on the expansion of small-scale irrigated agriculture in the region. Policy makers need to consider home gardens in their agriculture development programs.

\section{Materials and Methods}

\subsection{Description of Study Area}

This study was conducted in Lake Tana Basin (LTB), which is found in the northern part of Ethiopia. Lake Tana Basin is part of Abbay Basin, which is one of the largest basins in the nation (Figure 1) and comprises one of the largest lakes in Ethiopia (Lake Tana). LTB covers approximately $15,000 \mathrm{~km}^{2}$ area out of which Lake Tana covers $20 \%$. The mean annual rainfall in the basin ranges from $830 \mathrm{~mm}$ to $2500 \mathrm{~mm}$ from west to south of Lake Tana [33]. The rainfall distribution in the basin follows a mono-modal pattern that starts from mid-June and runs up to mid-September. Potential evapotranspiration over the basin ranges from $1216 \mathrm{~mm}$ at Debretabor station to $2200 \mathrm{~mm}$ at Shahura station. The temperature varies from minimum $\left(9.3^{\circ} \mathrm{C}\right)$ at Dangila to maximum $\left(29.6{ }^{\circ} \mathrm{C}\right)$ Gorgora for the period of 1997 to 2006 [34]. Lake Tana Basin has great economic importance in the nation for its high potential for irrigation, hydroelectric power generation and high yield crop production [35]. The basin has more than 40 rivers out of which Gilgel Abbay, Rib, Gumera, and Megech are the four major rivers that cover nearly $93 \%$ of the inflow into Lake Tana [36].

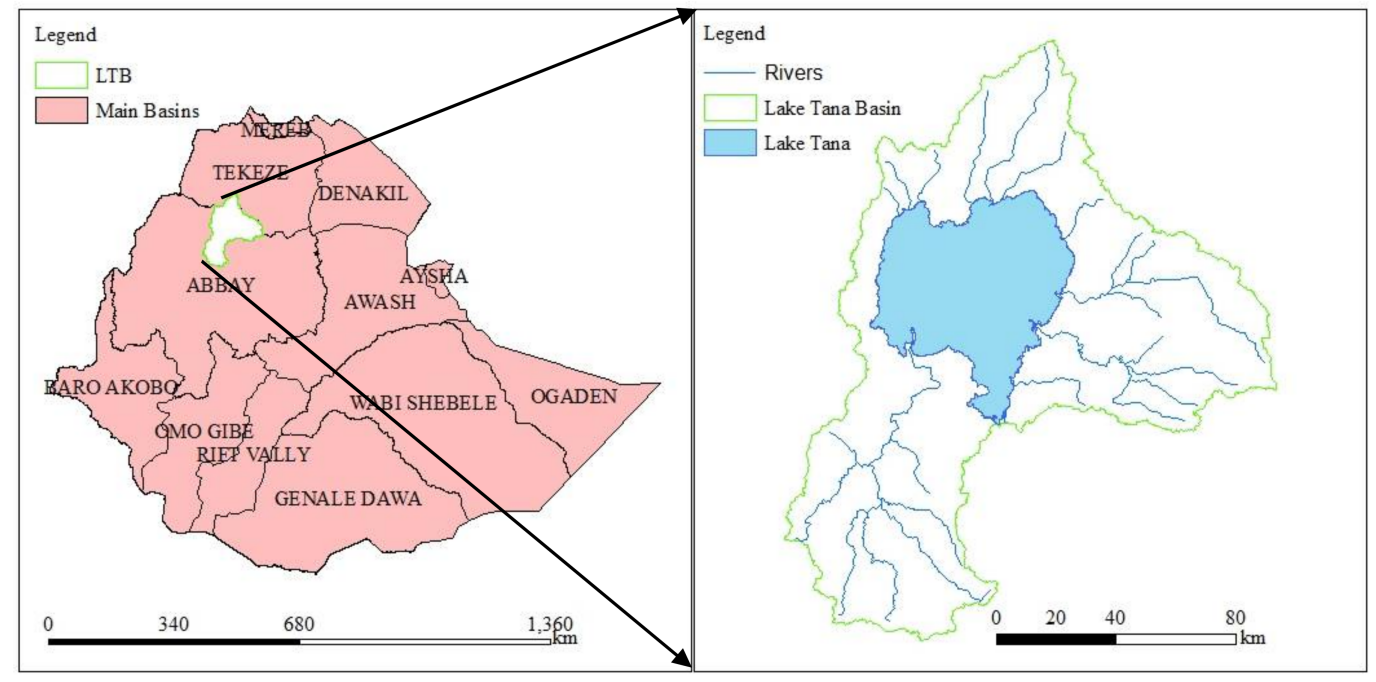

Figure 1. Location of Lake Tana Basin in Ethiopia. 
Necessary input data used in this study were collected from governmental organizations and online sources. Digital elevation model (DEM), $30 \mathrm{~m}$, was obtained from United States Geological Survey (USGS). Land use and soil were obtained from Amhara Design and Supervision Works Enterprise (ADSWE) and Ministry of Water and Energy (MoWE), respectively. Soil properties were obtained from Harmonized World Soil Database (HWSD). Groundwater depth and salinity were obtained from Amhara National Regional State Water Resources Bureau. Climate data was obtained from the Ethiopian National Meteorological Agency (ENMA). Roads, urban areas, and rivers were obtained from online map sources for Ethiopia. The input data were used to prepare criteria layers, which later used to produce irrigation suitability index map.

\subsection{Multi-Criteria Evaluation (MCE) Technique for the Assessment of Irrigable Land}

Assessment of potentially irrigable land was conducted using the Multi-Criteria Evaluation (MCE) technique. MCE technique, integrated with geographic information system (GIS), is an emerging approach for optimal decision-making and involves multiple spatially variable criteria [32,37-43]. Various researchers worldwide applied MCE explicitly for irrigation, agriculture and other environmental science $[14,16,29,44-50]$. There are several methods of combining factors for optimal decisions. The analytical hierarchy process (AHP) is widely used for water resource assessment $[16,51,52]$. The APH method is unique in decomposing complex problems into hierarchies of criteria [53] and is capable of deriving scales [54]. It is flexible and capable of evaluating consistency [55]. The mode is also tested and validated with several problems [56,57], and thus used for this study. Food and Agricultural Organization (FAO) guidelines are widely accepted for irrigation suitability criteria setup [32]. The FAO [58] briefly described the factors that could potentially affect irrigation systems and provide guidelines for criteria setup. Figure 2 shows the process of irrigable land assessment from surface and groundwater sources.

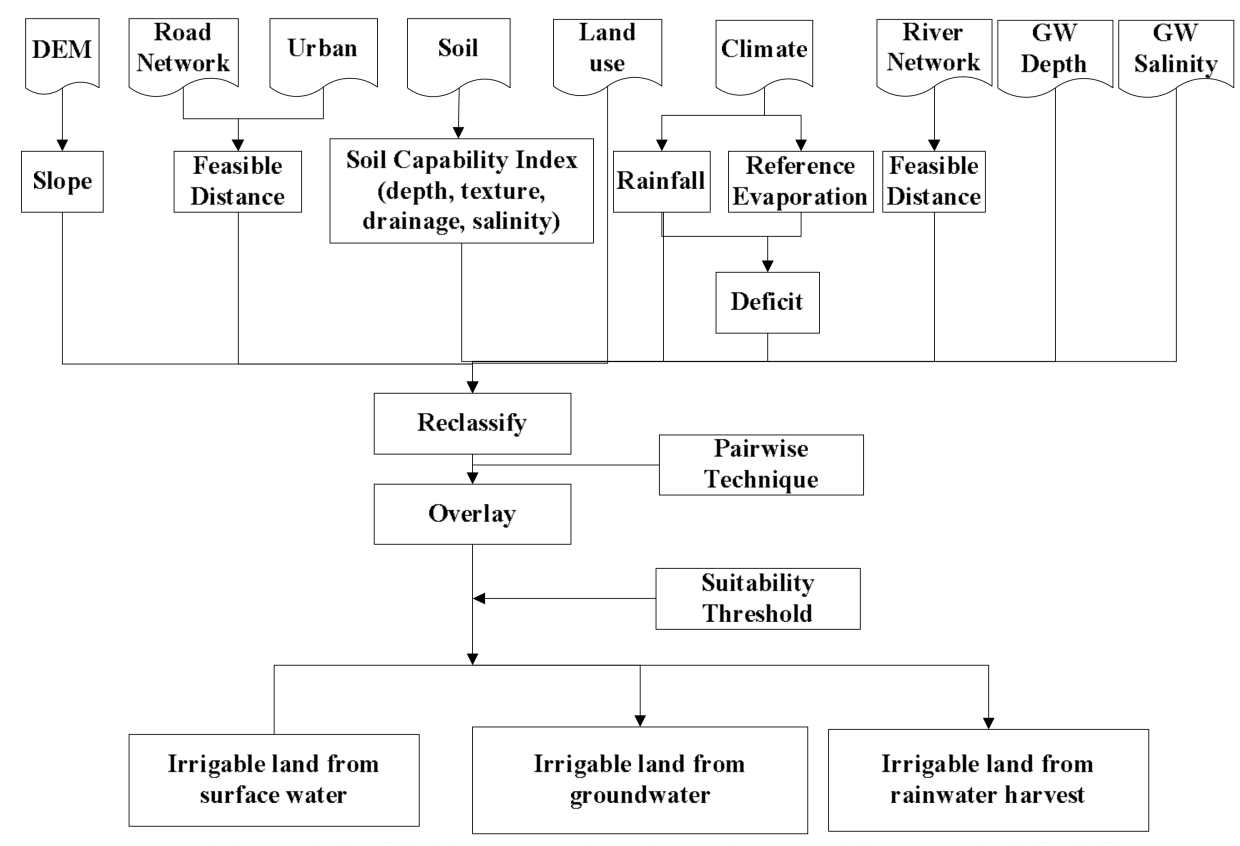

Figure 2. Method of identifying suitable land for irrigation (GW stands for groundwater).

Multiple criteria were considered for irrigation land suitability evaluation from rivers, groundwater and rainwater harvesting sources. Six factors were common among the water sources: road networks, topography, soil capability index (a function of soil characteristics), urban centers, climate and land cover. A total of seven criteria was considered for rivers and harvested rainwater sources including river networks and amount of rainfall, respectively, in addition to the common 
six factors. Moreover, a total of eight criteria were considered for groundwater sources including groundwater depth and salinity in addition to the common factors. A 30-m digital elevation model (DEM) was used to generate the landscape slope of Lake Tana the basin to represent the topographic factor. River networks, road networks, and urban areas were used to calculate Euclidean distance, which defines the proximity criteria for those factors (i.e., river, road and urban). The equal interval method was used to classify river, road, urban and rainfall deficit into various suitability classes based on [14]. Soil depth, texture, drainage class, and salinity were used to determine soil capability index (SCI), which is considered as a soil suitability factor. SCI is described as the ability of soil for irrigation practice (Equation (1)). Rating of soil characteristics was made based on [29,59]. Various land covers considered into different suitability classes based on [14]. Climatic data were used to derive rainfall deficit for further use. Mean annual rainfall over the basin was calculated from climate stations' data (Figure 3a). Groundwater depth and salinity were considered for irrigable land assessment from a groundwater source. Spline interpolation was used to compute groundwater depth and salinity over the basin from the measurement stations (Figure 3b). Gebregziabher [60] and Kumar et al. [61] criteria were considered to classify groundwater depth and salinity into suitability classes, respectively. Mean annual rainfall depth was considered for irrigable land from rainwater water harvesting sources. Nketiaa et al. [62] criteria were considered to classify mean annual rainfall into suitability classes. The mean annual evapotranspiration over the basin was computed by adjusting Piche evaporation measurements from climate stations (Figure 3a). Mean annual evapotranspiration was deducted from mean rainfall to derive mean annual rainfall deficit:

$$
\mathrm{SCI}=\mathrm{A} *(\mathrm{~B} / 100) *(\mathrm{C} / 100) *(\mathrm{D} / 100),
$$

where SCI is soil capability index; A is soil texture rating; B is soil depth rating; $\mathrm{C}$ is soil salinity rating, and $\mathrm{D}$ is soil drainage class rating.

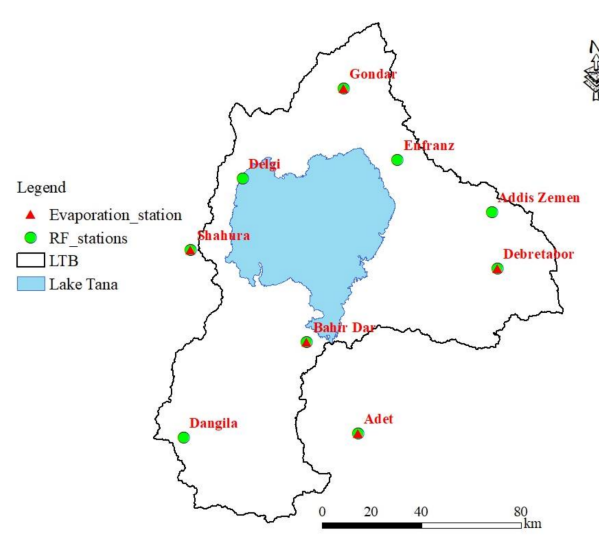

(a)

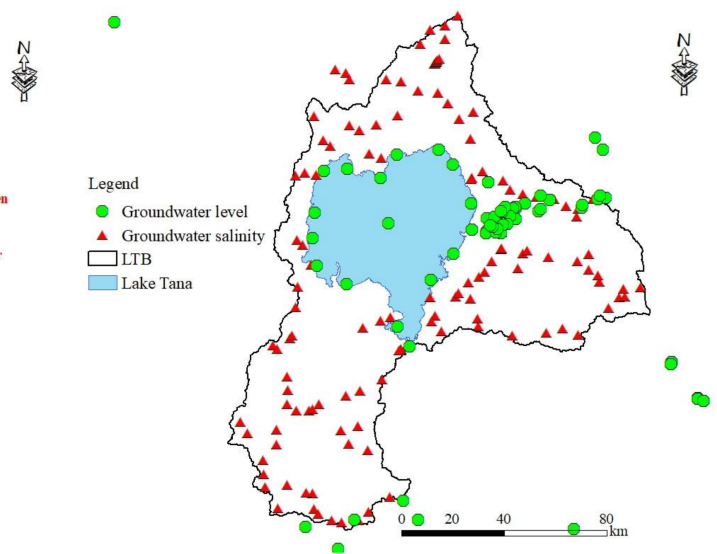

(b)

Figure 3. (a) Climate station; and (b) groundwater quality and salinity station over the basin.

The factors were reclassified to produce criteria layers using land suitability classes. According to the FAO [58], Wale et al. [63], and Worqlul et al. [14], land suitability is classified into five levels: highly suitable (S1), moderately suitable (S2), marginally suitable (S3), currently suitable (S4) and permanently unsuitable (N1). Permanently unsuitable land for irrigation within the basin includes water body (Lake Tana), wetlands, urban /built up/areas and protected areas. The suitability classes of each criteria layer were obtained from literature [14,29,60-63]. Factors weights were assigned based on experts' opinions, and the pairwise technique was used to compute the final weight for each factor. The experts were two professors from North Carolina A\&T State University, a postdoctoral research associate from Texas A\&M AgriLife Research \& Extension Center, and a professor from Bahir Dar 
University. Weighted sum overlay was used to combine all criteria layers and suitability threshold was applied to identify the most suitable irrigable land from various sources. A separate irrigation suitability map was produced for each source. According to Worqlul et al. [14], combined weights greater than or equal to $85 \%$ are considered a potentially irrigable land class. Further suitability classes were established based on an equal interval approach, greater or equal to $95 \%$, greater or equal to $90 \%$, and greater or equal to $85 \%$. The potential of surface water (rivers) and groundwater well yield to address the irrigable land in the dry season was determined and mapped based on water requirements of dominant crops in the region.

\subsection{Pairwise Comparison Technique}

Weights were assigned to each factor using a pairwise comparison technique based on Saaty [64], considering the relative importance of each factor for irrigation. The pairwise comparison technique provides a powerful, simplified and relatively unbiased ranking criterion [14]. A comparison matrix was established comparing each factor one-to-one based on pairwise scale. The scale is broken down from 1 to 9 (Table 1) in which the highest value (9) indicates absolute importance while the reciprocal $(1 / 9)$ indicates absolute triviality. The weights of each factor assigned by experts were averaged to construct a pairwise matrix.

Table 1. Pairwise scale based on Saaty [64].

\begin{tabular}{|c|c|c|}
\hline Importance & Definition & Explanation \\
\hline 1 & Equal importance & Two factors contribute equally to the objective \\
\hline 3 & Somewhat important & Experience and judgment slightly favor one over the other \\
\hline 5 & Much more important & Experience and judgment strongly favor one over the other \\
\hline 7 & Very much more important & $\begin{array}{l}\text { Experience and judgment very strongly favor one over the } \\
\text { other. Its importance is demonstrated in practice }\end{array}$ \\
\hline 9 & Absolutely more important & $\begin{array}{l}\text { The evidence favoring one over the other is of the highest } \\
\text { possibility validity }\end{array}$ \\
\hline $2,4,6,8$ & Intermediate values & When compromise is needed \\
\hline
\end{tabular}

The consistency of the pairwise matrix was checked using a consistency ratio (CR). A consistency ratio compares a consistency index $(\mathrm{CI})$ of the matrix being used with the consistency of a random-like matrix (CR) (Equation (2)) [65]. The procedures of calculating consistency ratio with examples can be found in Mu and Pereyra-Rojas [65]:

$$
\mathrm{CR}=\mathrm{CI} / \mathrm{RI},
$$

where $\mathrm{CR}, \mathrm{CI}$, and RI are a consistency ratio, a consistency index calculated from the pairwise matrix, and a consistency index of a randomly generated matrix, respectively.

\subsection{Surface and Groundwater Potential Assessment}

Low-flow characteristics are essential to determine the amount of water available in the river during the dry season. Low-flow is usually characterized using a Flow Duration Curve (FDC). FDC is the plot of the percent of the time that the flow in the river is equal to or exceeding a specified value of interest. Worqlul et al. [14] developed FDC using 27-year flow records (1980 to 2007) for the major four rivers in Lake Tana Basin. The 90-percentile flow $\left(\mathrm{Q}_{90}\right)$ is the discharge in the stream that occurs or is exceeded $90 \%$ of the time. In this study, $Q_{90}$ was used to determine the potential of the rivers in the dry season without any storage structures. The value of $Q_{90}$ for the major rivers was transferred to the ungauged catchment of other seven rivers considered within Lake Tana Basin by taking into account the regional homogeneity findings by Assefa [66]. The potential area that can be irrigated by the rivers in the dry season was calculated as the quotient of $Q_{90}$ and crop water requirement in the growing season [14]. Crop water requirement is the amount of water required to meet water loss 
mainly through evapotranspiration. The major rivers' catchments and the other seven rivers were delineated. In addition, the potential of seven dams along major rivers (Gilgel Abbay, Ribb, Gumara, Jemma, Koga, Megech, and Bebeks) was considered from McCartney et al. [67] and Easton et al. [68] to get an insight into the combined surface water potential. Groundwater well yield and crop water requirement were considered to determine groundwater availability and potential. The number of existing water supply wells in the suitable land was taken into consideration. The total number of wells that could be installed within the boundary of suitable land as determined by maintaining a minimum spacing of one kilometer between wells [69]. Worqlul et al. [14] developed the crop water requirement formula (Equation (3)) considering the dominant crops in Lake Tana Basin and conventional irrigation efficiency (60\% inefficiency). Maps were prepared to show the potential of surface and groundwater on the irrigable land:

$$
\mathrm{CWR}=1.84 \mathrm{ETo},
$$

where CWR is crop water requirement, and ETo is potential evapotranspiration.

\subsection{Applicability of Low-Cost Water-Lifting Technologies}

A total of seven water-lifting technologies were considered: rope and bucket, bucket pump, rope pump, suction plunger hand pump, direct action hand pump and deep wells' piston pump. Threshold depth and pumping capability of the water-lifting technologies were adopted from Brikké and Bredero [70]. Table 2 shows the operating depth and pumping capacity of water-lifting technologies. Nigussie et al. [71] indicated that some farmers used rope, and rope and bucket pump for small-scale irrigation.

Table 2. Suitability ranges for water-lifting technologies based on Brikké and Bredero [70].

\begin{tabular}{ccc}
\hline Technology & Operating Depth $(\mathbf{m})$ & Pumping Capacity (L/s) \\
\hline Rope and bucket & $0-15$ & 0.25 at $10 \mathrm{~m}$ \\
Bucket pump & $0-15$ & Relatively low, 0.16 \\
Rope pump & $0-50$ & 0.6 at $10 \mathrm{~m}$ and $0.15 \mathrm{~L} / \mathrm{s}$ at $50 \mathrm{~m}$ \\
Suction plunger hand pump & $0-7$ & 0.4 to 0.6 \\
Direct action hand pump & $0-12$ & $0.25-0.42 \mathrm{~L} / \mathrm{s}$ \\
Deep wells diaphragm pump & $10-70$ & 0.25 at $10 \mathrm{~m}, 0.32$ at $30 \mathrm{~m}, 0.24 \mathrm{~L} / \mathrm{s}$ at $45 \mathrm{~m}$ \\
Deep wells piston hand pump & $15-45$ & 0.25 to 0.36 at $25,0.18-0.28 \mathrm{~L} / \mathrm{s}$ at $45 \mathrm{~m}$ \\
\hline
\end{tabular}

\section{Results and Discussion}

For discussion, this section is categorized into four sub-sections as follows (Section 3.1 to Section 3.4).

\subsection{Factors Suitability Class}

Topography is one of the main factors affecting the efficiency of irrigation practices. It is described in terms of landscape slope calculated from a DEM. Worqlul et al. [14] considered four slope suitability classes: highly suitable (0-2\%), moderately suitable (2-8\%), marginally suitable (8-12\%), less suitable class (12-30\%) and unsuitable class (above 30\%). On the other hand, land cover is also one of the potential factors for irrigation land suitability assessment. Cultivated land is the dominant land use in Lake Tana Basin (56\%) followed by water body (about 20\%) and grassland (10.6\%). Land use types were classified into suitability class as follows: cultivated land (S1); grassland (S2); shrubs and bare land (S3); and forest and plantation (S4) [16]. Topography and land use types of Lake Tana Basin were reclassified into suitability classes (Figure $4 \mathrm{a}, \mathrm{b}$, respectively).

Proximity to river networks is the most important factor for irrigable land assessment from the surface water source. Agricultural land close to river networks can get access to water easily for crop production. Euclidean distances were calculated from each river and then an equal interval method 
was used for classification into suitability classes (Figure 5a). The soil is also one of the potential factors that influence irrigation practices. Awulachew et al. [72] explained soil texture suitability classes: highly suitable (fine to medium), moderately suitable (heavy clay), marginally suitable (course or poorly drained) and unsuitable class (very coarse) or shallow depth. Baniya [45] classified soil depth into various suitability classes: highly suitable (above $80 \mathrm{~cm})$, moderately suitable $(50-80 \mathrm{~cm})$, marginally suitable $(30-50 \mathrm{~cm}$ ) and unsuitable (below $30 \mathrm{~cm}$ ). Soil salinity was considered based on Awulachew et al. [72] classification: highly suitable $(0-0.5 \mathrm{dS} / \mathrm{m})$, moderately suitable $(0.5-2 \mathrm{dS} / \mathrm{m})$, marginally suitable (2-5 dS/m) and unsuitable (above $5 \mathrm{dS} / \mathrm{m}$ ).

Lake Tana Basin is dominated by Haplic Luvisols (21\%) followed by Chromic Luvisols (16\%), which are characterized as moderately well drained soils. The effect of soil characteristics was expressed using soil capability index (SCI), which is described as the ability of soil for irrigation practices. First, soil texture, depth, salinity, and drainage classes were used to compute the soil capability index (SCI). Physical and chemical properties of the soil types over the basin were obtained from the FAO soil database (Table 3) and rated out of $100 \%$ based on O'Geen [59] and Teka et al. [29]. Rating soil properties were made considering the capability of individual soil properties from the perspective of irrigation practice. SCI was then reclassified into different suitability classes based on Teka et al. [29] as follows: greater than 80 (S1); 60-80 (S2); 45-60 (S3); 30-45 (S4\%) and less than 30 (N1) (Figure 5b).

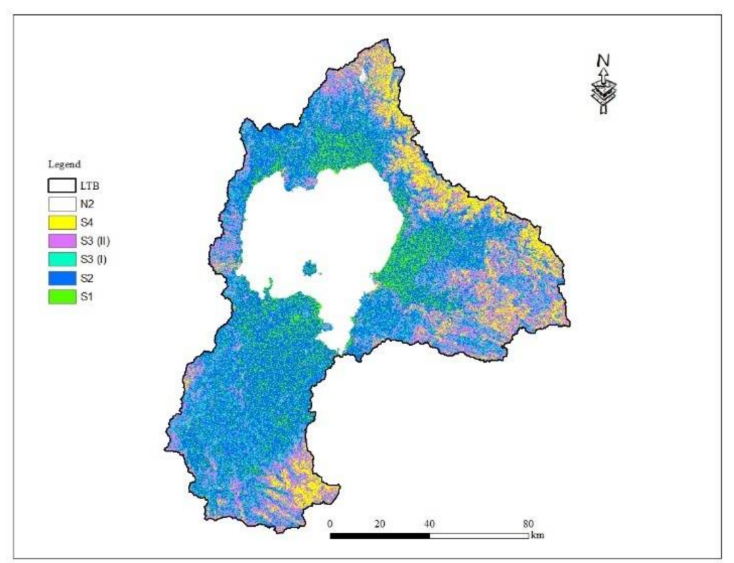

(a)

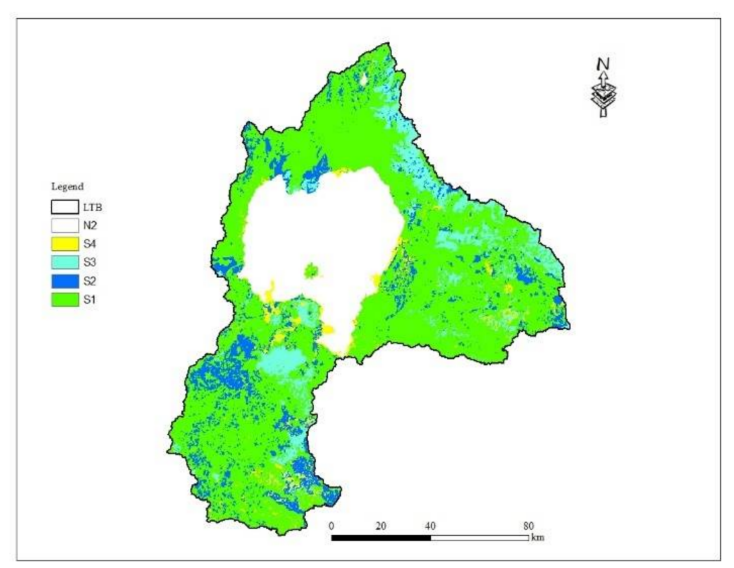

(b)

Figure 4. Reclassified factors (a) topography; and (b) land cover.

Table 3. Soil types in Lake Tana Basin and their characteristics from the FAO World Soil Database.

\begin{tabular}{cccccc}
\hline \multirow{2}{*}{ Soil Types } & \multicolumn{5}{c}{ Soil Rating } \\
\cline { 2 - 6 } & Depth & Texture & Drainage & Salinity & Soil Capability Index \\
\hline Eutric Fluvisoils & 95 & 95 & 90 & 99 & 80.4 \\
Haplic Alisols & 95 & 95 & 90 & 100 & 81.2 \\
Eutric Cambisols & 95 & 95 & 90 & 99 & 80.4 \\
Eutric Leptosols & 95 & 95 & 50 & 99 & 44.7 \\
Lithic Leptosols & 95 & 90 & 50 & 97 & 41.5 \\
Haplic Luvisols & 95 & 95 & 90 & 100 & 81.2 \\
Chromic Luvisols & 95 & 95 & 90 & 98 & 79.6 \\
Haplic Nitisols & 95 & 90 & 90 & 100 & 76.0 \\
Eutric Regosols & 95 & 95 & 85 & 100 & 43.8 \\
Eutric Vertisols & 95 & 94 & 50 & 98 & - \\
Water Bodies & - & - & - & - & - \\
Urban and Mining areas & - & - & - & - & \\
\hline
\end{tabular}


The market outlet is one of the main factors that affect irrigation suitability from all water sources because agricultural products need to get access to markets. The market outlet was considered based on proximity to road networks and urban centers together. All urban centers that were included in the nation town map within Lake Tana Basin are considered in this study. Agricultural lands close to road networks and urban centers are most likely to get access to markets. Euclidean distances were calculated from road networks and urban centers and then classified into suitability classes based on the equal interval approach (Figure 6a,b, respectively).

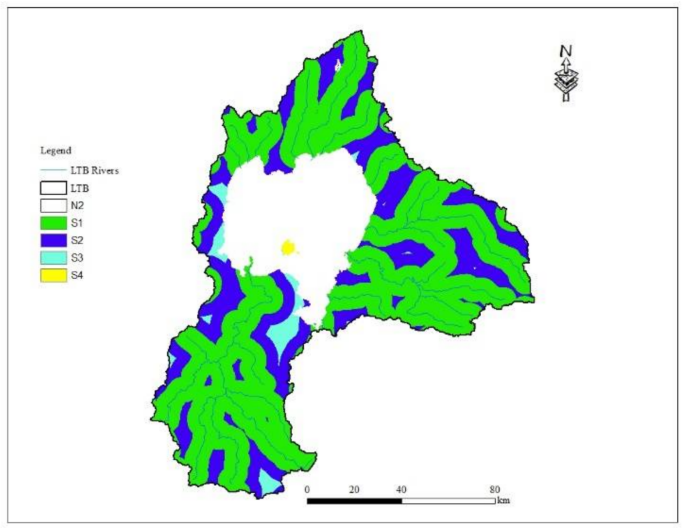

(a)

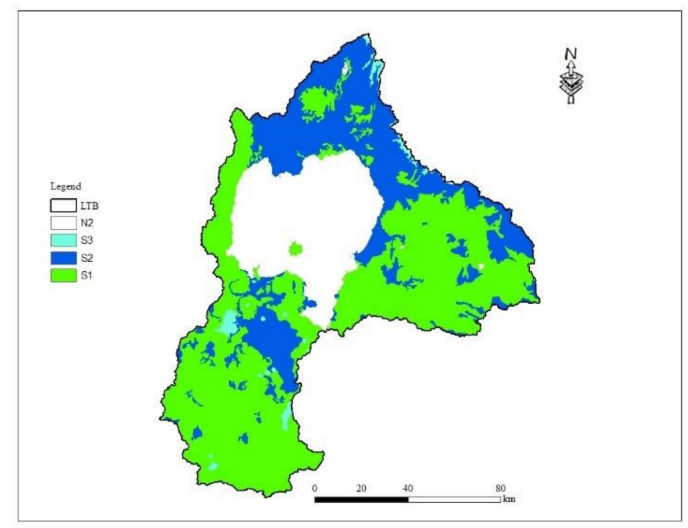

(b)

Figure 5. Reclassified factors (a) river proximity; and (b) soil capability index.

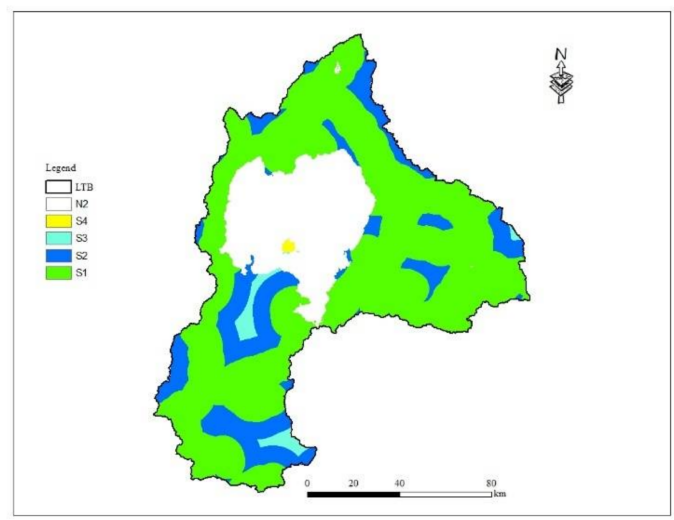

(a)

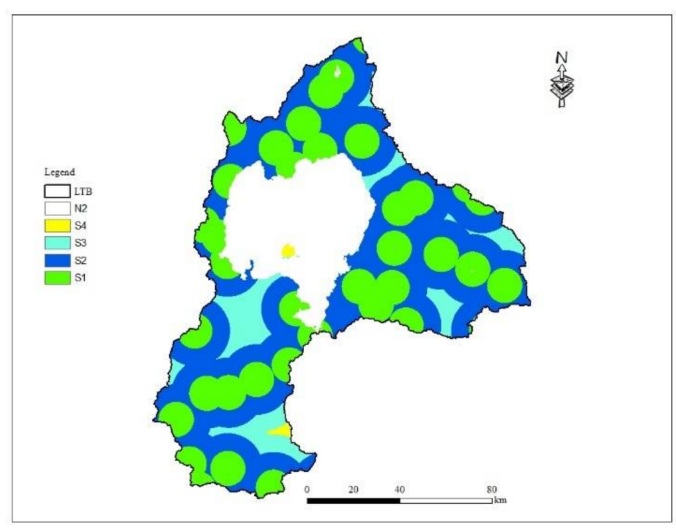

(b)

Figure 6. Reclassified factors (a) road proximity; and (b) town proximity.

Groundwater depth and salinity are important factors when considering irrigation from groundwater sources. Spline interpolation was used to find the spatial distribution of groundwater level and salinity over the basin. Groundwater table elevation was deducted from DEM to obtain groundwater depth from the surface. According to Gebregziabher [60], depth to groundwater less than $6 \mathrm{~m}$ (S1), 6-10 m (S2), 10-30 m (S3) and more than $30 \mathrm{~m}$ (S4). Similarly, Kumar et al. [61] classified groundwater salinity as follows: less than $250 \mu \mathrm{S} / \mathrm{cm}$ (S1), 250-750 $\mu \mathrm{S} / \mathrm{cm}$ (S2), 750-2000 $\mu \mathrm{S} / \mathrm{cm}$ (S3) and $2000-3000 \mu \mathrm{S} / \mathrm{cm}$ (S4). Groundwater depth and salinity were then reclassified based on suitability classes (Figure $7 \mathrm{a}, \mathrm{b}$ respectively).

Mean annual rainfall depth is one of the main factors considered for irrigation suitability analysis from harvested rainwater sources. Considering mean monthly rainfall, Addis Zemen station receives the highest rainfall in July followed by Debre Tabor and Bahir Dar stations (Figure 8a). Annual rainfall analysis showed that Dangila station receives the highest mean annual rainfall followed by Debretabor 
and Bahir Dar stations (Figure 8b). Delgi station receives the lowest rainfall considering both monthly and annual rainfall amounts. The highest rainfall record was observed in the southern and eastern part, whereas the lowest rainfall was observed in the northern and northwest part of the basin (Figure 8b). The rainy season was from June to September (Figure 8a).

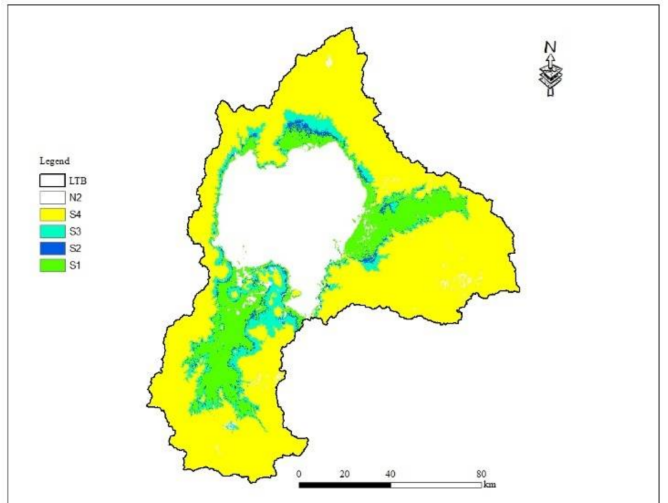

(a)

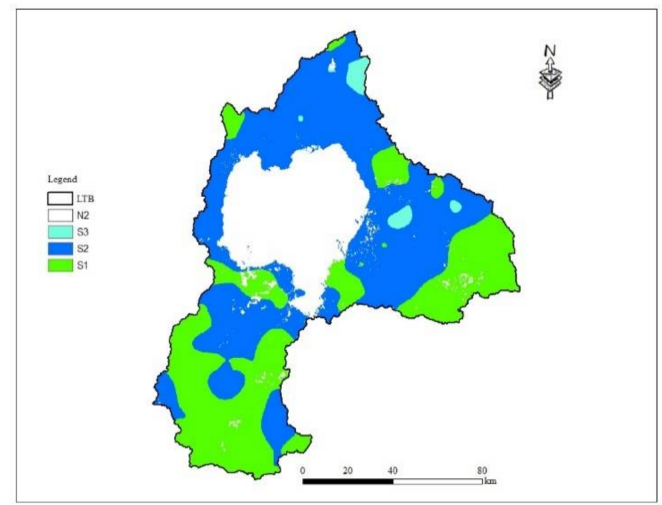

(b)

Figure 7. Reclassified factors (a) groundwater depth; and (b) groundwater salinity.

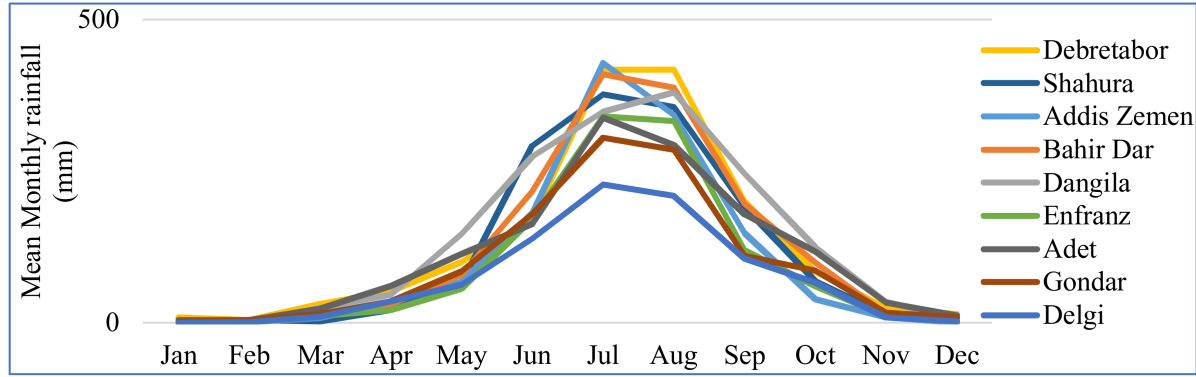

(a)

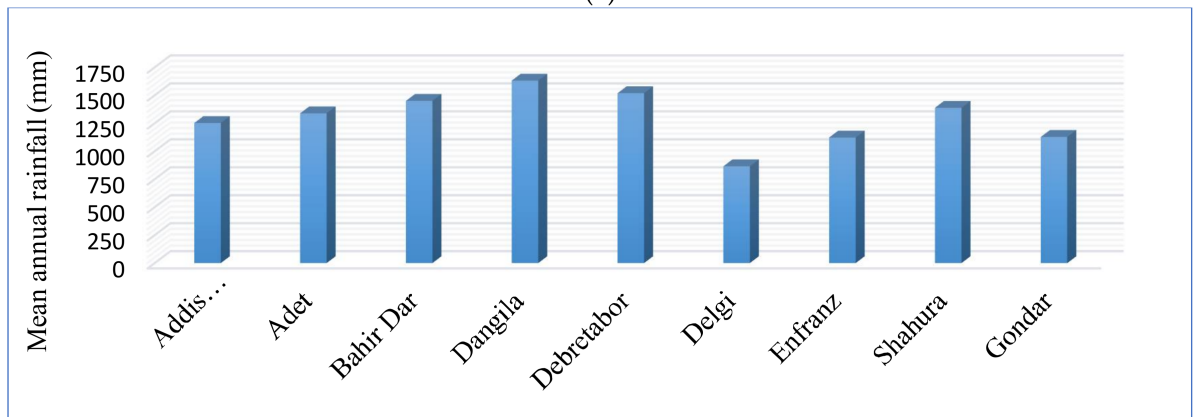

(b)

Figure 8. Rainfall depth (mm) (a) mean monthly; (b) mean annual.

The mean annual rainfall ranges from $862 \mathrm{~mm}$ to $1637 \mathrm{~mm}$ over the basin. According to Nketiaa et al. [62], mean annual rainfall can be classified as follows: above 900 mm (S1), 790-900 mm (S2), 640-790 mm (S3) and less than $640 \mathrm{~mm}$ (S4). Piche evaporation [73] measurement was obtained from five climate stations: Adet, Bahir Dar, Debretabor, Gondar, and Shahura. Penman-Monteith average monthly evapotranspiration was computed for Bahir Dar station and compared with mean monthly Piche evaporation measurements (Figure 9a). Piche evaporation was found overestimated during the dry season (November to May) and underestimated during the wet season (June to October). According to Stanhill [73], a linear relationship exists between Piche evaporation and Penman potential evapotranspiration indicating the possibility to derive monthly adjustment coefficients (Figure 8a). 
Monthly adjustment coefficients were derived and used to adjust the mean monthly (1992-2009) Piche measurements to other stations (Figure 9b). Evapotranspiration loss was found to be high in the northern and northwestern part of the basin (Figure 10a). The highest evapotranspiration record was observed from March to May.

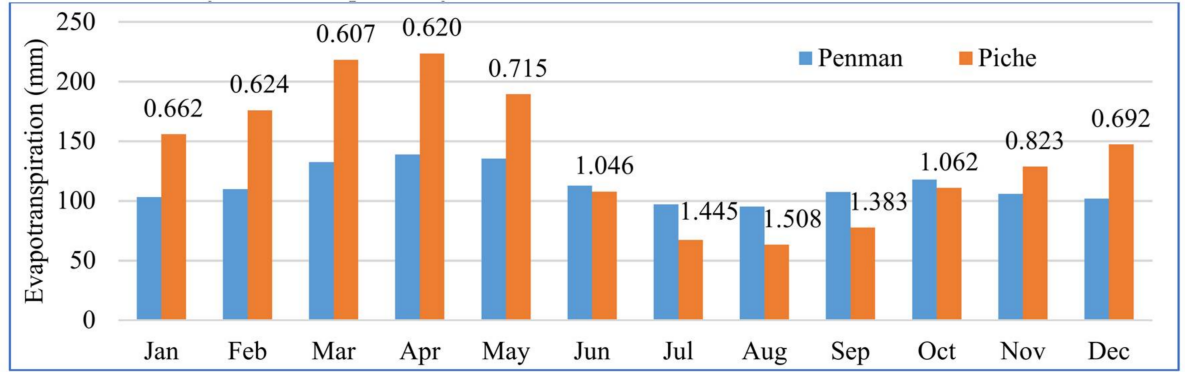

(a)

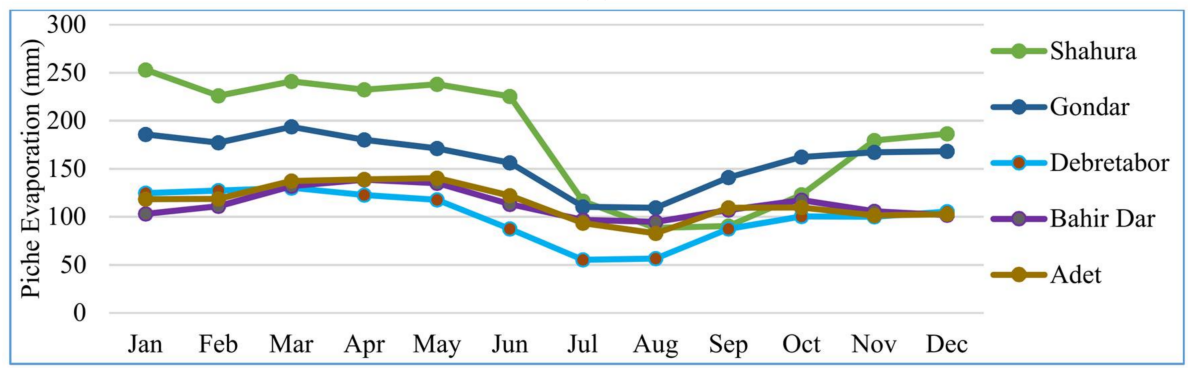

(b)

Figure 9. Evapotranspiration (a) Piche evaporation adjustment; (b) adjusted Piche evaporation.

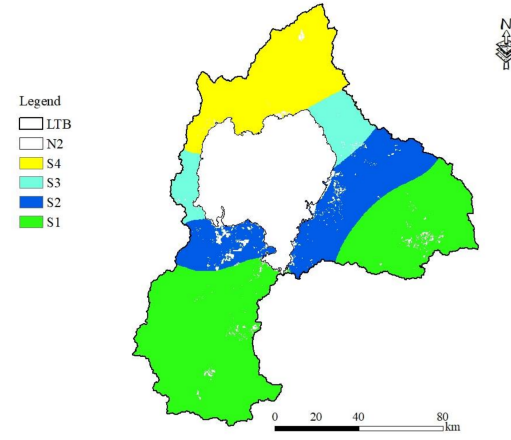

(a)

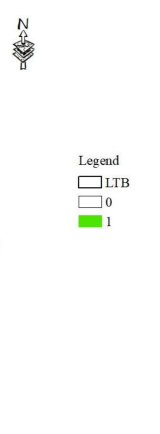

Figure 10. (a) Rainfall deficit suitability class; and (b) constraints.

Mean annual rainfall deficit was computed by deducting mean annual potential evapotranspiration from the mean annual rainfall. The equal interval method was used to classify the mean annual rainfall deficit into suitability classes (Figure 10a). Permanently unsuitable land (constraint), water body, wetlands, urban/built up areas and protected areas were taken away from factors' suitability class. Figure $10 \mathrm{~b}$ shows the constraint map where ' 0 ' and ' 1 ' denote constraints and various suitability classes, respectively.

Overall, suitability assessment of individual factors assists with partially characterizing the potential of Lake Tana Basin for irrigation. Lake Tana accounts for about $20 \%$ of the basin, which is considered as permanently unsuitable, constraint, (N2) for irrigation practice for all criteria. About $72 \%$ of the basin is suitable for irrigation practices when considering topography; S1 (9\%), S2 (34\%), and S3 (29\%), whereas the remaining $8 \%$ is currently unsuitable (S4). The easternmost and northernmost part of the basin has a steeper slope (i.e., less suitable for irrigation practice). About $77 \%$ of the land use is suitable for irrigation, 
S1 $(56 \%)$, S2 $(11 \%)$, and S3 $(10 \%)$, whereas S4 is about 3\%. Cultivated land is the dominant land use in the basin $(\sim 56 \%)$. The soil capability index results showed that the entire basin is suitable (except the constraint) for irrigation when soil characteristics are considered: S1 (51\%), S2 (27\%), and S3 (2\%). Proximity criteria (road, urban and river) were classified using an equal ranging technique, and the majority of the basin falls under suitability classes (S4 is less than 1\%). Groundwater depth and sanity were included for suitability assessment for irrigation from groundwater. About $22 \%$ of the basin is suitable for irrigation when groundwater depth is considered: S1 (13\%), S2 (2\%), and S3 (7\%), whereas the remaining $58 \%$ is $\mathrm{S} 4$. The majority of the irrigable land (based on groundwater depth) is found in the central and southern part of the basin. The entire basin is suitable for irrigation (except the constraint) when groundwater salinity is considered.

\subsection{Factors Weight and Assessment of Irrigable Land}

The pairwise weighting method was used to calculate the weights of each factor. The average of expert opinions was used for comparison of factors one-to-one. The eigenvector was calculated from a pairwise matrix based on Podvezko [74] as the $n$-th root of the product of values in rows. The cumulative eigenvector was used to calculate the final weights of each factor. The weight of factors was computed separately for rivers, rainfall (Table 4) and groundwater sources (Table 5) after normalizing the eigenvector with the cumulative value. In Table 4, river proximity was replaced with mean annual rainfall depth when computing the weight for irrigation suitability from rainwater harvesting sources while the remaining six parameters were the same.

Table 4. Irrigation suitability factors' weight calculation from river/rainwater harvest based on expert opinion.

\begin{tabular}{cccccccccc}
\hline \multicolumn{7}{c}{ Surface Water (River) and Rainwater Harvesting Pairwise Matrix } \\
\hline Factors & River & Road & Slope & Soil CI & Rainfall Urban & Land Use & Eigenvector & $\begin{array}{c}\text { Pairwise } \\
\text { Weights }\end{array}$ \\
\hline River & 1.0 & 7.0 & 3.0 & 3.0 & 9.0 & 3.0 & 5.0 & 3.6 & 38 \\
Road & 0.1 & 1.0 & 0.3 & 0.3 & 3.0 & 1.0 & 3.0 & 0.8 & 8 \\
Slope & 0.3 & 3.0 & 1.0 & 3.0 & 5.0 & 3.0 & 3.0 & 2.0 & 21 \\
Soil CI & 0.3 & 3.0 & 0.3 & 1.0 & 5.0 & 4.0 & 4.0 & 1.6 & 17 \\
Rainfall deficit & 0.1 & 0.3 & 0.2 & 0.2 & 1.0 & 0.3 & 3.0 & 0.4 & 4 \\
Urban & 0.3 & 1.0 & 0.3 & 0.3 & 3.0 & 1.0 & 3.0 & 0.8 & 9 \\
Land use & 0.2 & 0.3 & 0.3 & 0.3 & 0.3 & 0.3 & 1.0 & 0.3 & 4 \\
\hline
\end{tabular}

The consistency of pairwise matrix was checked, $C R=0.08$ and 0.005 , for surface and groundwater sources, respectively, and found to be trustworthy $(C R \leq 0.2)$ based on Chen et al. [75]. Based on the results of factors weight, proximity to rivers, rainfall, and groundwater depth were found to be the most influential factors from the surface, rainwater harvest, and groundwater sources, respectively. Slope and soil capability index were found to be the second and the third influential factors from surface water (Table 4), whereas groundwater salinity and slope were the second and the third influential factors for irrigation from groundwater (Table 5).

The weights were distributed to individual factors' suitability classes based on an equal interval ranging technique, and the factors were combined using weighted sum overlay. A total of seven criteria layers for surface water and rainwater harvesting sources and eight criteria for groundwater source were combined to produce the single suitability index. The value of the suitability index ranges from 0 (permanently unsuitable land) to 100 (most suitable land). Suitability threshold is a value that needs to be exceeded to determine potentially irrigable land. At $85 \%$ threshold, about 345,000 ha of land is suitable for irrigation from surface water sources (Figure 11a). The results depicted about $3 \%$ increment on the irrigable land when compared to Worqlul et al. [14]. The reason was that seven additional rivers, twenty-eight more urban centers and more refined road networks were considered in this study. Further suitability classes were established based on an equal interval approach (Figure 11b). 
The majority of the irrigable land, about $83 \%$ were in the three major river catchments: Gilgel Abbay ( $\sim 54 \%)$, Gumara ( 13\%) and Ribb ( 18\%). If an $80 \%$ suitability threshold was used, the irrigable land would be increased to about 594,000 ha.

Table 5. Irrigation suitability factors weight calculation from groundwater based on expert's opinion.

\begin{tabular}{ccccccccccc}
\hline \multicolumn{10}{c}{ Groundwater Sources Pairwise Matrix } \\
\hline Factors & GW Depth & Road & GW Salinity & Soil CI & Slope & RFD & Urban & Land Use & $\begin{array}{c}\text { Eigenvector } \\
\text { Pairwise } \\
\text { Weight }\end{array}$ \\
\hline GW depth & 1.0 & 7.0 & 0.3 & 5.0 & 3.0 & 7.0 & 3.0 & 7.0 & 2.9 & 28.0 \\
Road & 0.1 & 1.0 & 0.2 & 0.3 & 0.3 & 2.0 & 1.0 & 3.0 & 0.6 & 5.9 \\
GW salinity & 3.0 & 5.0 & 1.0 & 3.0 & 2.0 & 3.0 & 2.0 & 2.0 & 2.4 & 23.1 \\
Soil CI & 0.2 & 3.0 & 0.3 & 1.0 & 0.3 & 5.0 & 4.0 & 4.0 & 1.2 & 11.9 \\
Slope & 0.3 & 3.0 & 0.5 & 3.0 & 1.0 & 5.0 & 3.0 & 3.0 & 1.7 \\
RFD & 0.1 & 0.5 & 0.3 & 0.2 & 0.2 & 1.0 & 0.3 & 3.0 & 0.4 \\
Urban & 0.3 & 1.0 & 0.5 & 0.3 & 0.3 & 3.0 & 1.0 & 3.0 & 0.8 & 4.0 \\
Land use & 0.1 & 0.3 & 0.5 & 0.3 & 0.3 & 0.3 & 0.3 & 1.0 & 0.3 \\
\hline
\end{tabular}

Note: GW—groundwater depth, RFD—rainfall deficit.

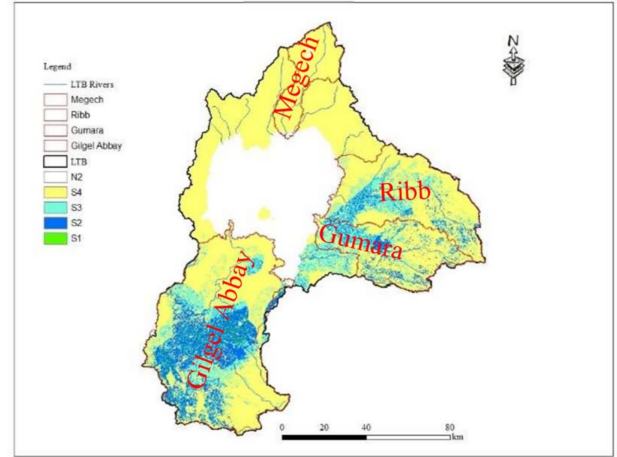

(a)

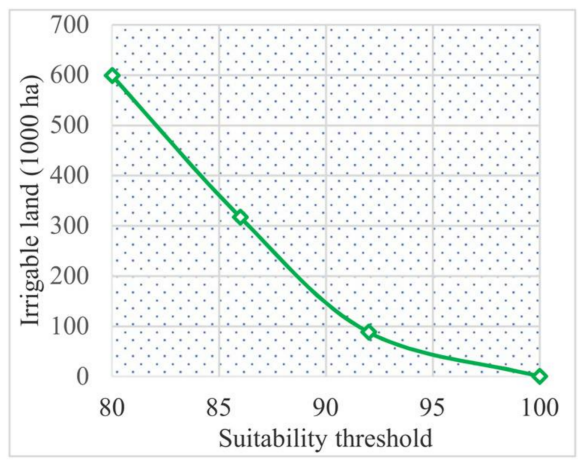

(b)

Figure 11. Irrigable land from rivers (a) 85\% threshold; and (b) various thresholds.

On the other hand, about 720,000 ha of land is irrigable using an $85 \%$ threshold from rainwater harvest considering average annual rainfall (Figure 12a). Further suitability classes were established based on an equal ranging approach (Figure 12b). The potential of the rainwater harvesting system depends on types, size, and location of structures. Biazin et al. [76] indicated the feasibility of macro-catchment rainwater harvesting in the long term despite the fact that the initial investment is high. Traditional open ponds, cisterns, earthen dams, and sand dams are among macro-catchment rainwater harvesting techniques. However, the average size of the farmer's plot is small, which is about 0.5 ha per household [77], and the use of rainwater harvesting structures could consume a substantial amount of land. In situ and micro-catchment rainwater harvesting could be feasible for smallholder farmers in the region. In situ rainwater harvesting includes mulching, ridging, furrowing and pot hoeing and conservation tillage, whereas micro-basins, contouring, and terracing are among micro-catchment rainwater harvesting techniques.

About 176,000 ha of the land is suitable for irrigation from groundwater considering $85 \%$ threshold (Figure 13a). If the $80 \%$ threshold were used, the irrigable land would be increased to about 277,000 ha. Irrigable land at various threshold levels is shown in Figure 13b. Groundwater depth was found to be the limiting factor for irrigation from a groundwater source. 


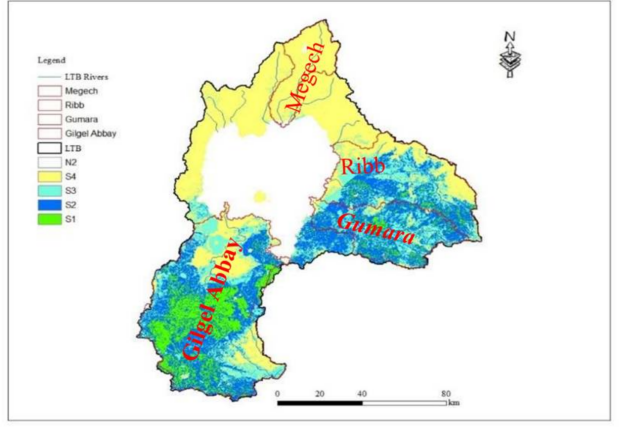

(a)

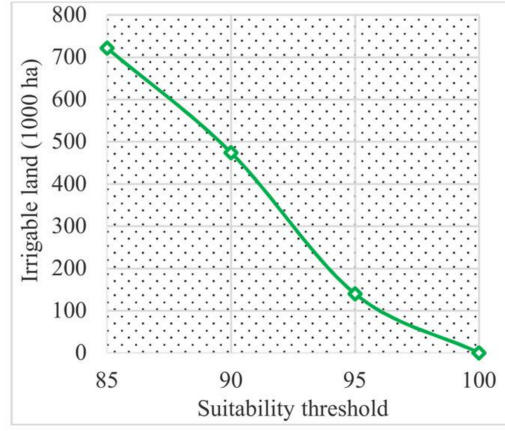

(b)

Figure 12. Irrigable land from rainwater harvest (a) $85 \%$ threshold; and (b) various thresholds.

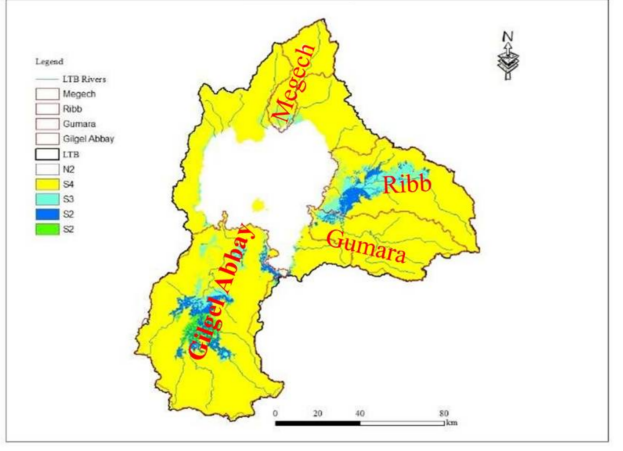

(a)

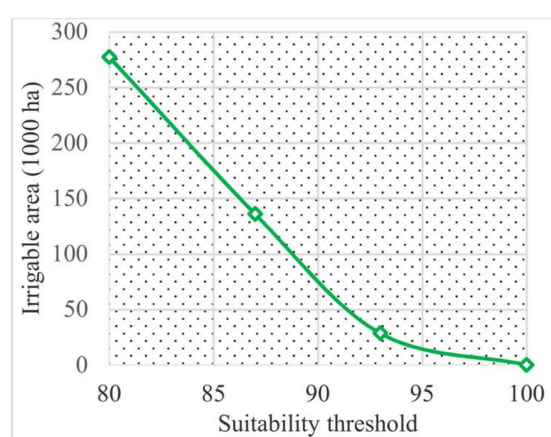

(b)

Figure 13. Irrigable land from groundwater (a) 85\% threshold; and (b) various thresholds.

\subsection{Surface and Groundwater Potential}

Analysis of mean monthly rainfall and crop water requirement was made for all river catchments. The consistency of monthly crop water requirement values was checked comparing calculated low-flow potential with [14]. The result depicted that the rainfall is sufficient to meet crop water need from June to September for Gilgel Abbay, Gumara and Ribb river catchments while other river catchments do not need irrigation for July and August. Crop water requirement within Lake Tana Basin was high from January through March. Low-flow $\left(\mathrm{Q}_{90}\right)$ potential of rivers was analyzed using conventional irrigation techniques. $Q_{90}$ potential of all rivers within the basin ranges from 3133 ha in April to 4142 ha in December. The Gilgel Abbay river has the highest $\mathrm{Q}_{90}$ potential $(1866 \mathrm{ha}$ ) followed by Gumara river (728 ha). About $91 \%$ of the $Q_{90}$ potential in the basin came from the four major rivers (Gilgel Abbay, Gumara, Ribb, and Megech); the other rivers can irrigate about 285 ha. $Q_{90}$ potential of rivers can only satisfy about $1-1.2 \%$ of the irrigable land. The potential of the rivers is limited if only surface water source is used without storage structures. If seven irrigation dams along the major rivers within the basin are considered, the combined potential would be 72,666 ha (Figure 14). Awulachew et al. [1] estimated the runoff generation from 12 river basins for Ethiopia to be about 125 billion $\mathrm{m}^{3}$ per year. Most of this potential is lost due to limited infrastructure to make adequate use of surface water [78]. This indicates the potential of irrigation dams and other water harvesting structures in maximizing potentially irrigable lands from surface water.

Crop water requirements in the regions and groundwater well yield were used to compute the potential of groundwater using conventional irrigation techniques. The potential of groundwater ranges from about 3873 ha in March to 4898 ha in November. About 1440 ha of land in Lake Tana Basin can be irrigated using either surface or groundwater sources (Figure 14). There are various constraints and opportunities to expand irrigated agriculture in the region from surface and groundwater sources. 
The cost of development and operation, cost of irrigation equipment, inadequate capacity and community involvement, irrigation input costs and lack of comprehensive understandings of water resources are among the major constraints for irrigation $[5,79,80]$, whereas availability of abundant water resources, climate and land suitability, the reliability of water resources, inexpensive labor, adaptation of promising approach and technologies are some of several opportunities to expand irrigated agriculture $[5,80]$.

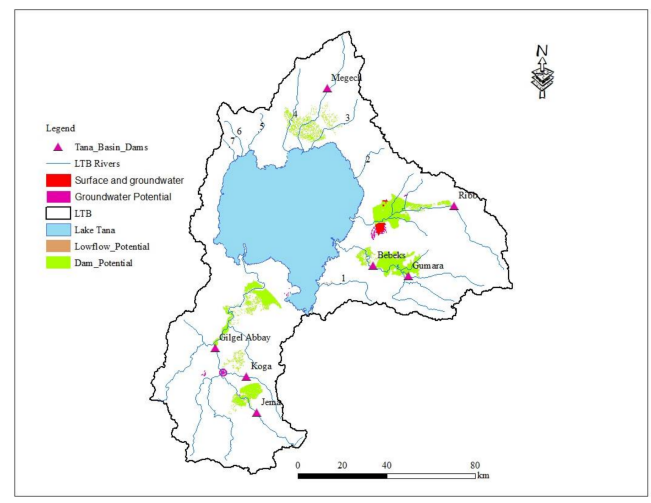

Figure 14. Irrigation potential of surface and groundwater on the irrigable land.

\subsection{Applicability of Low-Cost Water-Lifting Technologies}

The applicability of low-cost water-lifting technologies was identified comparing the operating depth and pumping capacity of the technologies with depth to groundwater and borehole yield in the region, respectively. The result showed that bucket pumps and direct-action hand pumps were found applicable on about 225,000 ha of land in the basin (Figure A1a,b, respectively). Bucket pumps use the simple system, easy to repair, have lower water yield and lower operation cost [70]. Maintenance of the direct-action hand pump is relatively simple. However, the cost of the system is fairly high [70]. Deep wells' diaphragm pumps and deep wells' piston hand pumps were found to be applicable on about 240,000 ha and 135,000 ha of lands in the basin, respectively (Figure A1c,d respectively). Deep wells' diaphragm pump can lift water from deeper depth to higher elevation [81]. Rope pumps and rope and bucket pumps were found applicable for on about 390,000 ha and 240,000 ha of lands in the basin (Figure Ale,f, respectively). Rope pumps were found the most applicable water-lifting technology as compared to other technologies considered in this study. Suction plunger hand pumps were found applicable on about 195,000 ha of land in the basin (Figure A1g). These water-lifting technologies can be used by smallholder farmers and helps to expand irrigated agriculture using groundwater sources.

\section{Conclusions}

Assessment of irrigable land, water availability and applicability of low-cost water-lifting technologies for home gardens were conducted in Lake Tana Basin. Multiple factors were considered for the assessment of irrigable land; and river networks, urban centers, road networks, land use/cover, soil characteristics, landscape slope, rainfall depth and deficit, groundwater depth and salinity were the factors considered. About $12 \%, 23 \%$ and $48 \%$ of the basin are potentially irrigable from groundwater, surface water, and rainwater harvest sources, respectively. Rainfall deficit, groundwater depth, and topography were found to be the most limiting factors for irrigation. The rivers can only satisfy about $1-1.2 \%$ of the irrigable land using conventional irrigation techniques. The irrigation potential of rivers in Lake Tana Basin was found very small compared to available irrigable land. Similarly, groundwater can only satisfy about $2.2-2.4 \%$ of the irrigable land using conventional irrigation techniques. About 1440 ha is suitable for both surface and groundwater sources, and stakeholders may decide the source 
based on feasibility of costs. The potential of water resources could be with efficient water application technology, such as drip irrigation. Applicability of seven low-cost water-lifting technologies in Lake Tana Basin was evaluated considering the operating depth and pumping capacity. Rope pumps have the highest percent applicability $(26 \%=390,000 \mathrm{ha})$, whereas deep wells' piston hand pumps have the least applicability $(\sim 9 \%=135,000$ ha) in the basin. Cost and benefit analysis is recommended to select the most appropriate technology whenever more than one technology is found to be applicable.

Acknowledgments: This publication was made possible through support provided by Feed the Future through the U.S. Agency for International Development, under the terms of Contract No. AID-OAA-A-13-0005. The opinions expressed herein are those of the author(s) and do not necessarily reflect the views of the U.S. Agency for International Development. We would also like to acknowledge the National Meteorological Agency Services of Ethiopia, Amhara Design and Supervision Works Enterprise, and Ministry of Water and Energy of Ethiopia for providing us with quality data. The editor and the two anonymous reviewers are gratefully acknowledged for their valuable comments on our manuscript.

Author Contributions: Tewodros Assefa contributed to method development, data collection, result analysis and manuscript development; Manoj Jha contributed to method development and analysis of results; Manuel Reyes contributed to the analysis of the results; Raghavan Srinivasan contributed to the analysis of the results; Abeyou Worqlul contributed to method development, data and result analysis.

Conflicts of Interest: The authors declare no conflict of interest.

\section{Appendix A}

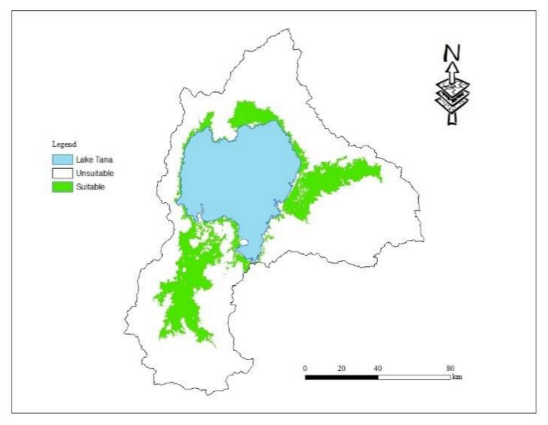

(a)

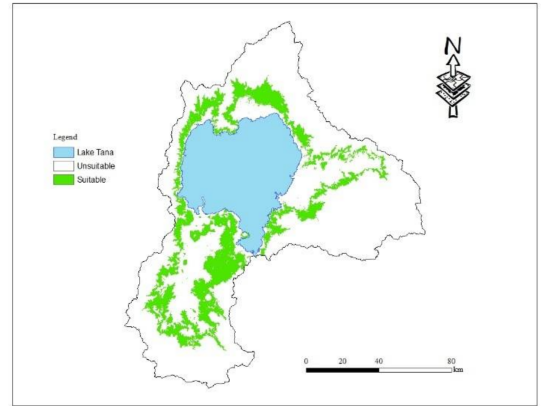

(c)

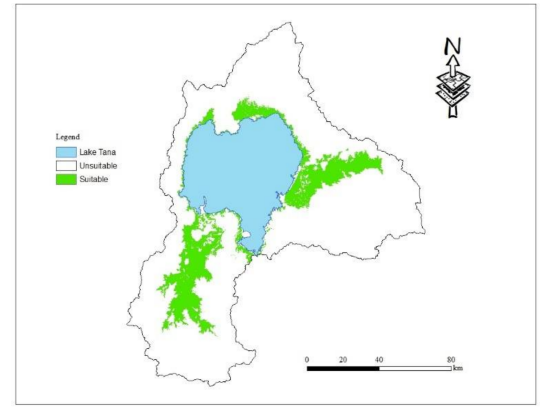

(e)

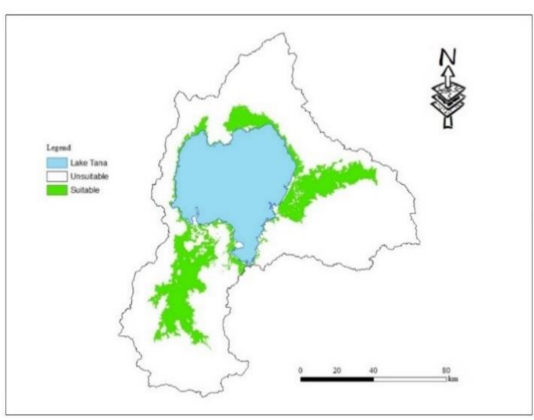

(b)

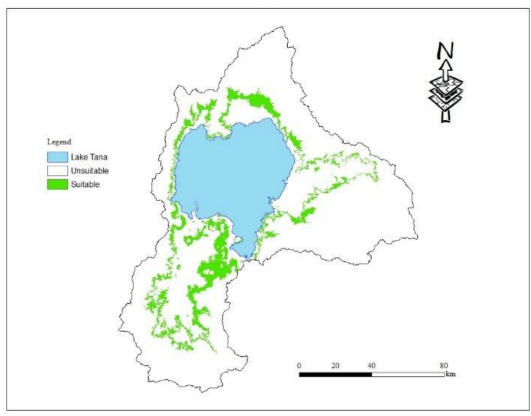

(d)

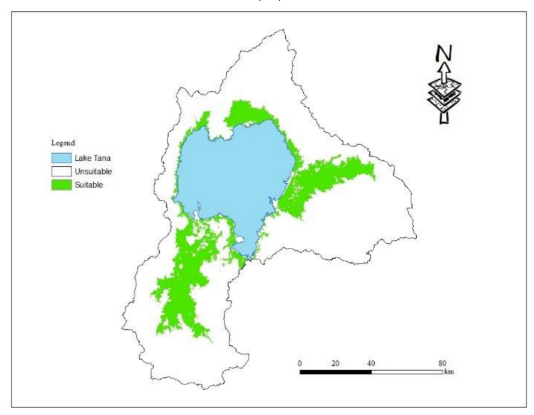

(f)

Figure A1. Cont. 


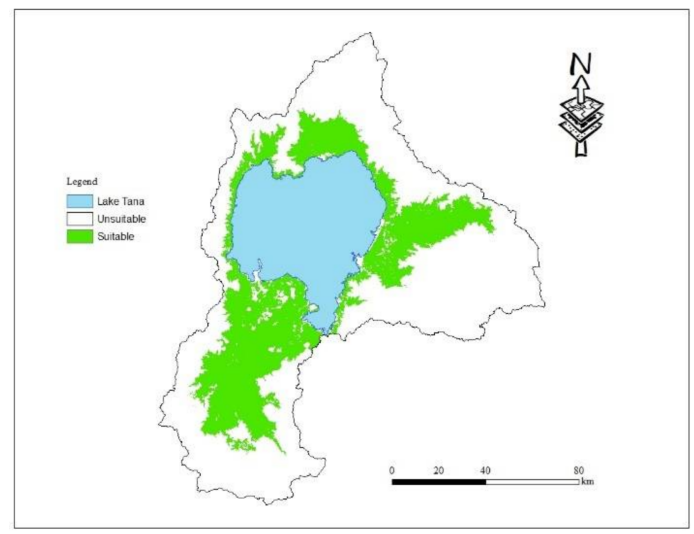

(g)

Figure A1. Applicability of different water-lifting technologies. (a) bucket pump; (b) direct action hand pump; (c) deep wells' diaphragm pump; (d) deep wells' piston hand pump; (e) rope pumps; (f) Rope and bucket pumps; (g) suction plunger hand pumps.

\section{References}

1. Awulachew, S.B.; Yilma, A.D.; Loulseged, M.; Loiskandl, W.; Ayana, M.; Alamirew, T. Water Resources and Irrigation Development in Ethiopia; International Water Management Institute (IWMI): Colombo, Sri Lanka, 2007; Volume 123.

2. Ngigi, S.; Thome, J.; Waweru, D.; Blank, H. Low-Cost Irrigation for Poverty Reduction: An Evaluation of Low-Head Drip Irrigation Technologies in Kenya; Annual Report 2000-2001; International Water Management Institute (IWMI): Colombo, Sri Lanka, 2001; pp. 23-29.

3. Bekele, A.E. Five key constraints to small scale irrigation development in Ethiopia: Socio-economic view. Glob. Adv. Res. J. 2014, 3, 441-444.

4. Awulachew, S.B.; Loulseged, M.; Yilma, A.D. Impact of irrigation on poverty and environment in Ethiopia. In Proceedings of the Draft Proceeding of the Symposium and Exhibition, Addis Ababa, Ethiopia, 27-29 November 2007.

5. Awulachew, S.; Erkossa, T.; Namara, R. Irrigation Potential in Ethiopia: Constraints and Opportunities for Enhancing the System; International Water Management Institute: Colombo, Sri Lanka, 2010.

6. Gebreselassie, S. Intensification of smallholder agriculture in Ethiopia: Options and scenarios. In Proceedings of the Future Agricultures Consortium Meeting, Institute of Development Studies, Brighton, UK, 20-22 March 2006; Institute of Development Studies: Brighton, UK; pp. 20-22.

7. Lankford, B. The right irrigation? Policy directions for agricultural water management in Sub-Saharan Africa. Water Altern. 2009, 2, 476-480.

8. Fanzo, J.; Haddad, L. Smallholder Food Production and Poverty Reduction: Principles for a Financial Coordination Mechanism to Support Smallholder Farmers, Ad Hoc Advisory Group to the Madrid Conference on Food Security Chaired by Prof. Jeffrey Sachs; Fundacion Ideas Foundation: Madrid, Spain, 2009; pp. 34-36.

9. Galhena, D.H.; Freed, R.; Maredia, K.M. Home gardens: A promising approach to enhance household food security and wellbeing. Agric. Food Secur. 2013, 2, 8. [CrossRef]

10. Merrey, D.J.; Langan, S. Review Paper on 'Garden Kits' in Africa: Lessons Learned and the Potential of Improved Water Management; IWMI Working Paper No. 162; International Water Management Institute (IWMI): Colombo, Sri Lanka, 2014.

11. Aworinde, D.; Erinoso, S.; Ogundairo, B.; Olanloye, A. Assessment of plants grown and maintained in home gardens in Odeda area southwestern Nigeria. J. Hortic. For. 2013, 5, 29-36.

12. Taylor, J.R.; Lovell, S.T. Urban home food gardens in the global north: Research traditions and future directions. Agric. Hum. Values 2014, 31, 285-305. [CrossRef] 
13. Ojiewo, C.O.; Tenkouano, A.; Yang, R. The role of AVRDC-The world vegetable center in vegetable value chains. Afr. J. Hortic. Sci. 2010, 3, 1-23.

14. Worqlul, A.W.; Collick, A.S.; Rossiter, D.G.; Langan, S.; Steenhuis, T.S. Assessment of surface water irrigation potential in the ethiopian highlands: The lake tana basin. Catena 2015, 129, 76-85. [CrossRef]

15. Mehari, A.; Van Steenbergen, F.; Schultz, B. Modernization of spate irrigated agriculture: A new approach. Irrig. Drain. 2011, 60, 163-173. [CrossRef]

16. Worqlul, A.W.; Jeong, J.; Dile, Y.T.; Osorio, J.; Schmitter, P.; Gerik, T.; Srinivasan, R.; Clark, N. Assessing potential land suitable for surface irrigation using groundwater in Ethiopia. Appl. Geogr. 2017, 85, 1-13. [CrossRef]

17. Mahari, A.; Alebachew, A. Land suitability evaluation for irrigation in Dejen District, Ethiopia. Int. J. Sci. Res. Publ. 2013, 3.

18. Rabia, R.A.; Harb, A.; Figueredo, H.; Huong, T.; Lopez, B.; Solomon, H.; Alessandro, V. Land suitability analysis for policy making assistance: A GIS based land suitability comparison between surface and drip irrigation systems. Int. J. Environ. Sci. Dev. 2013, 4, 1-6. [CrossRef]

19. Senzanje, A.; Simalenga, T.E.; Jiyane, J. Definition and Categorization of Small-Scale Water Infrastructure; Technical Brief No. 01; Agricultural Research Council Publications: Pretoria, South Africa, 2012.

20. Tilahun, H.; Paulos, D. Results to date and future plan of research on irrigation and its impact. In Proceedings of the Workshop on Impact of Irrigation on Poverty and Environment, Addis Ababa, Ethiopia, April 2004.

21. Ulsido, M.D.; Alemu, E. Irrigation water management in small scale irrigation schemes: The case of the Ethiopian rift valley lake basin. Environ. Res. Eng. Manag. 2014, 67, 5-15. [CrossRef]

22. Bhattarai, M.; Pandey, S. The economics of wheat production in the rice-wheat system in Nepal. In Applications of Systems Approaches at the Farm and Regional Levels; Springer: Berlin, Germany, 1997; Volume 1, pp. 45-52.

23. Ahmed, A.U.; Sampath, R.K. Effects of irrigation-induced technological change in Bangladesh rice production. Am. J. Agric. Econ. 1992, 74, 144-157. [CrossRef]

24. Vaidyanathan, A.; Krishnakumar, A.; Rajagopal, A.; Varatharajan, D. Impact of irrigation on productivity of land. J. Indian Sch. Political Econ. 1994, 6, 601-645.

25. Lipton, M.; Litchfield, J.; Faurès, J.-M. The effects of irrigation on poverty: A framework for analysis. Water Policy 2003, 5, 413-427.

26. Hussain, I.; Hanjra, M.A. Irrigation and poverty alleviation: Review of the empirical evidence. Irrig. Drain. 2004, 53, 1-15. [CrossRef]

27. Ayele, G.K.; Nicholson, C.; Collick, A.S.; Tilahun, S.A.; Steenhuis, T.S. Impact of small-scale irrigation schemes on household income and the likelihood of poverty in the Lake Tana basin of Ethiopia. In Proceedings of the Nile Basin Development Challenge Science Meeting, Addis Ababa, Ethiopia, 9-10 July 2013; Volume 98.

28. MacDonald, A.M.; Calow, R.C.; MacDonald, D.M.; Darling, W.G.; Dochartaigh, B.E. What impact will climate change have on rural groundwater supplies in Africa? Hydrol. Sci. J. 2009, 54, 690-703. [CrossRef]

29. Teka, K.; Van Rompaey, A.; Poesen, J. Land suitability assessment for different irrigation methods in Korir Watershed, Northern Ethiopia. J. Drylands 2010, 3, 214-219.

30. Sultan, D. Assessment of irrigation land suitability and development of map for the Fogera catchment using GIS, South Gondar. Asian J. Agric. Rural Dev. 2013, 3, 7-17.

31. Abraham, M.; Daniel, H.; Abeba, N.; Tigabu, D.; Temesgen, G.; Hagos, G. GIS based land suitability evaluation for main irrigated vegetables in Semaz Dam, Northern Ethiopia. Res. J. Agric. Environ. Manag. 2015, 4, 158-163.

32. Ayalew, G. Land suitability evaluation for surface and sprinkler irrigation using geographical information system (GIS) in Guang Watershed, highlands of Ethiopia. J. Environ. Earth Sci. 2014, 4, 140-149.

33. Worqlul, A.W.; Maathuis, B.; Adem, A.A.; Demissie, S.S.; Langan, S.; Steenhuis, T.S. Comparison of rainfall estimations by TRMM 3B42, mpeg and CFSR with ground-observed data for the Lake Tana basin in Ethiopia. Hydrol. Earth Syst. Sci. 2014, 18, 4871-4881. [CrossRef]

34. Steenhuis, T.S.; Collick, A.S.; Easton, Z.M.; Leggesse, E.S.; Bayabil, H.K.; White, E.D.; Awulachew, S.B.; Adgo, E.; Ahmed, A.A. Predicting discharge and sediment for the Abay (Blue Nile) with a simple model. Hydrol. Process. 2009, 23, 3728-3737. [CrossRef] 
35. Setegn, S.G.; Rayner, D.; Melesse, A.M.; Dargahi, B.; Srinivasan, R. Impact of climate change on the hydroclimatology of Lake Tana basin, Ethiopia. Water Resour. Res. 2011, 47, W04511. [CrossRef]

36. Tegegne, G.; Hailu, D.; Aranganathan, S.M. Lake tana reservoir water balance model. Int. J. Appl. Innov. Eng. Manag. 2013, 2, 474-478.

37. Malczewski, J. GIS-based multicriteria decision analysis: A survey of the literature. Int. J. Geogr. Inf. Sci. 2006, 20, 703-726. [CrossRef]

38. Greene, R.; Devillers, R.; Luther, J.E.; Eddy, B.G. GIS-based multiple-criteria decision analysis. Geogr. Compass 2011, 5, 412-432. [CrossRef]

39. Laaribi, A.; Chevallier, J.; Martel, J.-M. A spatial decision aid: A multicriterion evaluation approach. Comput. Environ. Urban Syst. 1996, 20, 351-366. [CrossRef]

40. Malczewksi, J.; Ogryczak, W. The multiple criteria location problem: 2. Preference-based techniques and interactive decision support. Environ. Plan. A 1996, 28, 69-98. [CrossRef]

41. Chakhar, S.; Martel, J.-M. Enhancing geographical information systems capabilities with multi-criteria evaluation functions. J. Geogr. Inf. Decis. Anal. 2003, 7, 47-71.

42. Carver, S.J. Integrating multi-criteria evaluation with geographical information systems. Int. J. Geogr. Inf. Syst. 1991, 5, 321-339. [CrossRef]

43. Chuvieco, E. Integration of linear programming and GIS for land-use modelling. Int. J. Geogr. Inf. Sci. 1993, 7, 71-83. [CrossRef]

44. Maddahi, Z.; Jalalian, A.; Zarkesh, M.M.K.; Honarjo, N. Land suitability analysis for rice cultivation using multi criteria evaluation approach and GIS. Eur. J. Exp. Biol. 2014, 4, 639-648.

45. Baniya, M.S.N. Land Suitability Evaluation Using GIS for Vegetable Crops in Kathmandu Valley/Nepal. Ph.D. Thesis, Institute of Horticulture Science, Humboldt-Universität zu Berlin, Berlin, Germany, 2008.

46. Hossain, M.S.; Chowdhury, S.R.; Das, N.G.; Rahaman, M.M. Multi-criteria evaluation approach to GIS-based land-suitability classification for tilapia farming in Bangladesh. Aquac. Int. 2007, 15, 425-443. [CrossRef]

47. Chen, Y.; Khan, S.; Padar, Z. Irrigation intensification or extensification assessment: A GIS-based spatial fuzzy multi-criteria evaluation. In Proceedings of the 8th International Symposium on Spatial Accuracy Assessment in Natural Resources and Environmental Sciences, Shanghai, China, 25-27 June 2008; pp. 309-318.

48. Chen, Y.; Khan, S.; Paydar, Z. To retire or expand? A fuzzy GIS-based spatial multi-criteria evaluation framework for irrigated agriculture. Irrig. Drain. 2010, 59, 174-188. [CrossRef]

49. Tu, Q.; Li, H.; Wang, X.; Chen, C.; Luo, Y.; Dwomoh, F.A. Multi-criteria evaluation of small-scale sprinkler irrigation systems using grey relational analysis. Water Resour. Manag. 2014, 28, 4665-4684. [CrossRef]

50. Assefa, T.T.; Jha, M.K.; Tilahun, S.A.; Yetbarek, E.; Adem, A.A.; Wale, A. Identification of Erosion Hotspot Area using GIS and MCE Technique for Koga Watershed in the upper Blue Nile Basin, Ethiopia. Am. J. Environ. Sci. 2015, 11, 245-255. [CrossRef]

51. Chen, Y.; Yu, J.; Khan, S. Spatial sensitivity analysis of multi-criteria weights in GIS-based land suitability evaluation. Environ. Model. Softw. 2010, 25, 1582-1591. [CrossRef]

52. Mendas, A.; Delali, A. Integration of multicriteria decision analysis in GIS to develop land suitability for agriculture: Application to durum wheat cultivation in the region of Mleta in Algeria. Comput. Electron. Agric. 2012, 83, 117-126. [CrossRef]

53. Macharis, C.; Springael, J.; De Brucker, K.; Verbeke, A. PROMETHEE and AHP: The design of operational synergies in multicriteria analysis: Strengthening PROMETHEE with ideas of AHP. Eur. J. Oper. Res. 2004, 153, 307-317. [CrossRef]

54. Millet, I.; Wedley, W.C. Modelling risk and uncertainty with the analytic hierarchy process. J. Multi-Criteria Decis. Anal. 2002, 11, 97-107. [CrossRef]

55. Ramanathan, R. A note on the use of the analytic hierarchy process for environmental impact assessment. J. Environ. Manag. 2001, 63, 27-35. [CrossRef] [PubMed]

56. Ishizaka, A.; Labib, A. Analytic hierarchy process and expert choice: Benefits and limitations. OR Insight 2009, 22, 201-220. [CrossRef]

57. Saaty, T.L. Decision making with the analytic hierarchy process. Int. J. Serv. Sci. 2008, 1, 83-98. [CrossRef]

58. Food and Agriculture Organization (FAO). A Framework for Land Evaluation; Soils Bulletin No. 32; FAO: Rome, Italy, 1976.

59. O'Geen, A.T. A Revised Storie Index for Use with Digital Soils Information; University of California Division of Agriculture and Natural Resources (UCANR) Publication: Oakland, CA, USA, 2008. 
60. Gebregziabher, G. Water Lifting Irrigation Technology Adoption in Ethiopia: Challenges and Opportunities. AgWater Case Study. Available online: http:/ / awm-solutions.iwmi.org/Data/Sites/3/Documents/PDF/etwater-lifting-devices.pdf (accessed on 15 November 2017).

61. Kumar, M.; Kumari, K.; Ramanathan, A.; Saxena, R. A comparative evaluation of groundwater suitability for irrigation and drinking purposes in two intensively cultivated districts of Punjab, India. Environ. Geol. 2007, 53, 553-574. [CrossRef]

62. Nketiaa, A.K.; Forkuob, E.K.; Asamoaha, E.; Senayaa, J.K. Using a GIS-based model as a decision support framework for identifying suitable rain water harvesting sites. Water Resour. 2013, 21, 26.

63. Wale, A.; Collick, A.S.; Rossiter, D.G.; Langan, S.; Steenhuis, T.S. Realistic Assessment of Irrigation Potential in the Lake Tana Basin, Ethiopia. In Proceedings of the Nile Bain Development Challenge Science Meeting, Nairobi, Kenya, 9-10 July 2013.

64. Saaty, T.L. A scaling method for priorities in hierarchical structures. J. Math. Psychol. 1977, 15, $234-281$. [CrossRef]

65. Mu, E.; Pereyra-Rojas, M. Understanding the analytic hierarchy process. In Practical Decision Making; Springer: Berlin, Germany, 2017; pp. 7-22.

66. Assefa, K. Flood Forecasting and Early Warning in Lake Tana Sub Basin, Upper Blue Nile, Ethiopia; WaterMill Working Paper Series, No.16; Unesco-IHE: Delft, The Netherlands, 2008.

67. McCartney, M.; Alemayehu, T.; Shiferaw, A.; Awulachew, S. Evaluation of Current and Future Water Resources Development in the Lake Tana Basin, Ethiopia; IWMI Working Paper 134; International Water Management Institute (IWMI): Colombo, Sri Lanka, 2010; Volume 134, 39p.

68. Easton, Z.; Fuka, D.; White, E.; Collick, A.; Biruk Ashagre, B.; McCartney, M.; Awulachew, S.; Ahmed, A.; Steenhuis, T. A multi basin swat model analysis of runoff and sedimentation in the Blue Nile, Ethiopia. Hydrol. Earth Syst. Sci. 2010, 14, 1827-1841. [CrossRef]

69. Howsam, P.; Carter, R.C. Water Policy: Allocation and Management in Practice, Proceedings of International Conference on Water Policy; E\&FN Spon: London, UK; CRC Press: Boca Raton, FL, USA, 2003.

70. Brikké, F.; Bredero, M. Linking Technology Choice with Operation and Maintenance in the Context of Community Water Supply and Sanitation: A Reference Document for Planners and Project Staff; World Health Organization; IRC Water and Sanitation Centre: Geneva, Switzerland, 2003.

71. Nigussie, L.; Lefore, N.; Schmitter, P.; Nicol, A. Gender and Water Technologies: Water Lifting for Irrigation and Multiple Purposes in Ethiopia; ILRI: Nairobi, Kenya, 2017.

72. Awulachew, S.B.; Merrey, D.; Kamara, A.; Van Koppen, B.; Penning de Vries, F.; Boelee, E. Experiences and Opportunities for Promoting Small-Scale/Micro Irrigation and Rainwater Harvesting for Food Security in Ethiopia; Working Paper No. 98; IWMI: Colombo, Sri Lanka, 2005; pp. 13-26.

73. Stanhill, G. The use of the Piche evaporimeter in the calculation of evaporation. Q. J. R. Meteorol. Soc. 1962, 88, 80-82. [CrossRef]

74. Podvezko, V. Application of AHP technique. J. Bus. Econ. Manag. 2009, 181-189. [CrossRef]

75. Chen, L.; Chan, C.-M.; Lee, H.-C.; Chung, Y.; Lai, F. Development of a decision support engine to assist patients with hospital selection. J. Med. Syst. 2014, 38, 59. [CrossRef] [PubMed]

76. Biazin, B.; Sterk, G.; Temesgen, M.; Abdulkedir, A.; Stroosnijder, L. Rainwater harvesting and management in rainfed agricultural systems in Sub-Saharan Africa-A review. Phys. Chem. Earth Parts A/B/C 2012, 47, 139-151. [CrossRef]

77. MoA. Small-Scale Irrigation Situation Analysis and Capacity Needs Assessment; Directorate of Natural Resources, Ministry of Agriculture (MoA): Addis Ababa, Ethiopia, 2011.

78. Awulachew, S.B.; Ahmed, A.; Haileselassie, A.; Yilma, A.; Bashar, K.; McCartney, M.; Steenhuis, T. Improved Water and Land Management in the Ethiopian Highlands and Its Impact on Downstream Stakeholders Dependent on the Blue Nile; CPWF Project Number 19; CGIAR Challenge Program on Water and Food Project Report Series; 2010; Available online: www.waterandfood.org (accessed on 15 November 2017).

79. Sisay, B.; Abebe, B. A critical review of small scale irrigation in Ethiopia: Prospects and challenges. Int. J. Curr. Res. 2017, 9, 60916-60920. 
80. Haile, G.G.; Kasa, A. Irrigation in Ethiopia: A review. Acad. J. Agric. Res. 2015, 3, 264-269.

81. Kumar, S.K.; Dispenzieri, A.; Lacy, M.Q.; Gertz, M.A.; Buadi, F.K.; Pandey, S.; Kapoor, P.; Dingli, D.; Hayman, S.R.; Leung, N. Continued improvement in survival in multiple myeloma: Changes in early mortality and outcomes in older patients. Leukemia 2014, 28, 1122-1128. [CrossRef] [PubMed] 